\title{
Secondary metabolic profiling and antibacterial activities of different species of Usnea collected in Northern Philippines
}

\section{Santiago $\mathrm{KAA}^{1^{*}}$, Sangvichien $\mathrm{E}^{2}$, Boonpragob $\mathrm{K}^{2}$ and dela Cruz TEE ${ }^{1}$}

\author{
${ }^{1}$ The Graduate School \& Fungal Biodiversity and Systematics Group, Research Center for the Natural and Applied \\ Sciences, University of Santo Tomas, España 1015 Manila, Philippines \\ ${ }^{2}$ Faculty of Science, Ramkhamhaeng University, Hua Mark, Bangkok 10240, Thailand
}

Santiago KAA, Sangvichien E, Boonpragob K, dela Cruz TEE 2013 - Secondary metabolic profiling and antibacterial activities of different species of Usnea collected in Northern Philippines. Mycosphere 4(2), 267-280, Doi 10.5943/mycosphere/4/2/10

Lichen metabolites have multiple functions in nature and these include several biological activities against pathogens and multi-drug resistant bacteria. This study shows the antibacterial properties of 18 Usnea species collected from five provinces in the northern part of Luzon, Philippines. A total of 41 lichen specimens were extracted using acetone to a final concentration of $10 \mathrm{mg} / \mathrm{ml}$. The crude extracts were initially subjected to TLC. Interestingly, 17 different lichen metabolites were identified. The 41 crude lichen extracts were then tested against Staphylococcus aureus and Bacillus subtilis using paper-disk diffusion assay, most of which were found to be more active against the latter test organism. In addition, 28 of the 41 lichen extracts were also tested against Mycobacterium phlei. Interestingly, most of the samples exhibited much greater activities than that of the antibiotics used as indicated by the zones of inhibition. Moreover, 15 crude extracts showing distinct spots in their TLC profiles were tested against Nocardia asteroides using TLCbioautography. Results showed that usnic acid, norstictic acid, and salazinic acid were the bioactive lichen metabolites.

Key words - acid-fast bacilli - gram-positive bacteria - lichen acids - paper disk diffusion assay TLC bioautography

\section{Article Information}

Received 17 January 2013

Accepted 11 March 2013

Published online 5 April 2013

*Corresponding author: Santiago KAA - email - kasantiago2012@gmail.com

\section{Introduction}

The challenge for today's pharmaceutical industry lies in the discovery of new pharmacologically active molecules (Behera et al. 2005). Human activities such as deforestation have led to the destruction of natural habitats that force resident animals to get in closer contact with people in search of food. This scenario exposes man to many new emerging disease-causing microorganisms. It is also known that many pathogenic microorganisms have developed resistance to many of our available antibiotics (Rankovic et al. 2007). In addition, the indiscriminate use of 
antibiotics tends to further accelerate this natural phenomenon. This rise in antibiotic resistance is the reason for the re-emergence of infectious diseases which caused over 9.5 million deaths worldwide in 2008 (WHO 2008). Therefore, the search for new drugs which can combat these "re-born microorganisms" is of primary concern, particularly to developing countries like the Philippines.

Natural products have played an important and crucial role in the discovery of new drugs (Butler \& Buss 2006). The effectiveness of these natural product-derived drugs can be attributed to the presence of various secondary metabolites (Butler \& Buss 2006). In fact, of the 520 approved drugs by the US Food and Drug Administration between 1983 and 1994, 39\% were derived from natural products; $60-80 \%$ of these were antibacterial and anti-cancer drugs (Harvey 2000). Currently, over 100 natural product-derived compounds are undergoing clinical trials while approximately 100 similar projects are in preclinical development (Harvey 2008). Interestingly, one promising source of bioactive natural products are the lichens. Lichens produce secondary metabolites, mainly by the mycobiont alone, and they are secreted onto the surface of the lichen's hyphae either in amorphous forms or as crystals (Türk et al. 2003). These secondary metabolites are unique with respect to those of higher plants (Müller 2001). Some of the common lichen secondary metabolites include depsides, depsidones, dibenzofurans, xanthones, and terpene derivatives (Karagöz et al. 2009). Chemical studies on these secondary metabolites led to the isolation of many new substances, which today number over 800 (Müller 2001, Russo et al. 2008, Karagöz et al. 2009). These metabolites are also known for their biological and/or pharmacological activities such as antiviral, antibiotic, anti-inflammatory, antimycobacterial, antitumoural, anti-allergenic, anti-herbivoral, and antiproliferative activities and for inhibition of plant growth (Müller 2001, Ranković et al. 2007). The wide variety of biological activities exhibited by these lichens and lichen natural products is generally correlated to their special ecological circumstances (Boustie \& Grube 2005).
The lichen genus Usnea (family Parmeliaceae) has a world-wide distribution (Ohmura 2010). About 600 species of Usnea are reported (Hawksworth et al. 1995), and it is the only genus within Parmeliaceae with the highest number of species (Randlane et al. 2009). In the Philippines, 32 species of Usnea have been reported (Wainio 1909, Herre 1963, Bawingan et al. 2000). Antibacterial activities of selected species of Usnea from the Philippines were also reported (Quisumbing 1951, Santos et al. 1964, Santiago et al. 2010). For example, usnic acid, a lichen acid reported from Usnea, exhibited antimicrobial activity against gram-positive bacteria and mycobacteria. The mechanism of this lichen substance is still unknown. However, studies have shown that its action may be due to its ability to inhibit RNA transcription (Francolini et al. 2004). In addition, it was recently found that usnic acid plays an important role in the acidity tolerance of lichens and is an intrinsic cause of their $\mathrm{SO}_{2}$ sensitivity (Hauck \& Jürgens 2008). Elo et al. (2007) also found that the lichen metabolite usnic acid has a potent activity against methicillin-resistant Staphylococcus aureus (MRSA) and vancomycin-resistant enterococci (VRE). The present research shows the antibacterial activities and the secondary metabolic profiles of different species of Usnea from five provinces within Luzon Island, Northern Philippines. In future, these metabolites may be synthesized for the production of novel antimicrobial agents against several diseases, particularly diseases caused by multi-drug resistant bacteria.

\section{Methods}

\section{Study Sites and the Collected Usnea}

Luzon Island $\left(14^{\circ} 35^{\prime} \mathrm{N}, 121^{\circ} 00\right)$, the largest in the Philippines, is located on the northern part of the Philippine archipelago. It is bounded by the Philippine Sea on the east and the West Philippines Sea on the west. Luzon has a typical tropical climate having two distinguishable seasons: wet (June-November) and dry (March-May). Usnea species were collected at different elevations: Benguet (1,600 meters above sea level, masl), Cavite (640 masl), Ifugao (2,500 masl), Mountain 
Province (1,700 masl), and Nueva Vizcaya (1,500 masl) (Table 1). These lichen specimens were identified to the species level following comparison of their morphology with published keys (Goward 1999, Randlane 2009).

\section{Extraction of Lichen Acids}

Lichen acids were extracted from 41 specimens of Usnea (Table 1). Initially, one gram of the air-dried lichen thallus was ground using mortar and pestle until powdery. The powdered thallus was placed in a clean, $16 \mathrm{x}$ $150 \mathrm{~mm}$ screw-capped test tube. Then, $10 \mathrm{ml}$ of acetone (RCI LabScan, Thailand) was added and the mixture allowed to stand overnight. Following soaking, the extracts were filtered using a funnel and filter paper and were placed in small, pre-weighed vials. The crude extracts were concentrated by air-drying for 4-5 days or until the extracts crystallized. Then, the weight of the extract for each specimen was determined and the percent yield (PY) was computed as weight of crude extracts over the weight of lichen thalli. Finally, the lichen crude extracts were reconstituted with acetone to a final concentration of $10 \mathrm{mg} / \mathrm{ml}$ and stored in a refrigerator.

\section{Detection of Lichen Acids using Thin Layer Chromatography}

The lichen crude extracts were subjected to thin layer chromatography (TLC) in order to determine the lichen acids present. Initially, the lichen crude extracts and lichen acid standards (i.e., atranorin, norstictic acid and salazinic acid) were spotted on silica gel TLC plates (silica gel $60 \mathrm{~F}_{254}$ aluminum plates, Merck) using disposable capillary tubes. The TLC plates were then run in three solvent systems: (1) solvent system A: 36:9:1 toluene/dioxane/glacial acetic acid, (2) solvent system C: 20:3 toluene/glacial acetic acid and (3) solvent system G: 139:83:8 toluene/ethyl acetate/formic acid (Elix \& Stocker-Wörgötter 2008). Solvent system A is reputed to owe its distinctive characteristics to the ability of dioxane to associate with phenolic hydroxyl groups. Solvent system $\mathrm{C}$ is an excellent general solvent for a wide variety of different compounds while solvent system $G$ is particularly useful in separating compounds with relatively low $\mathrm{Rf}$ values in solvents $\mathrm{A}$ and C (Elix \& Stocker-Wörgötter 2008). Each TLC plate was then sprayed with $97 \%$ sulphuric acid and heated at $110^{\circ} \mathrm{C}$ for 10 minutes following the methods of Santos \& Mondragon (1969). Visible spots were traced and their retention factor (Rf) values were computed. The Rf values and chemical properties of each spot were compared to the lichen acid standards from published literatures (Culberson et al. 1972) for the identification of each lichen metabolite.

\section{Assay for Antibacterial Activities}

Test Bacteria. The test bacteria used for the assay were (1) gram-positive bacteria: Staphylococcus aureus (ATCC 25923), Bacillus subtilis (environmental isolate), and (2) acid-fast bacilli: Nocardia asteroides (DMST 2872), Mycobacterium phlei (UPCC 1365). All bacterial strains were maintained on nutrient agar slants (NA, Hi-Media) in a refrigerator.

Paper Disk Diffusion Assay. Forty-one lichen crude extracts were tested for their inhibitory activities against $B$. subtilis and $S$. aureus (Table 1). The test bacteria were initially grown on NA plates at $37^{\circ} \mathrm{C}$ for 24 hours. Following incubation, inoculum was prepared by suspending bacterial cells in normal saline solution (NSS, $0.85 \% \mathrm{NaCl}$ ) and adjusted to $0.5 \mathrm{McFarland}$ standard. The test bacteria were then swabbed heavily onto culture plates pre-filled with $25 \mathrm{ml}$ Mueller Hinton agar (MHA, Hi-Media). Then, $30 \mu \mathrm{l}$ of each of the extracts with a concentration of 10 $\mathrm{mg} / \mathrm{ml}$ was added to antibiotic paper disks (Whatmann, $6 \mathrm{~mm}$ diam.) and allowed to dry in a separate sterile petri dish. As positive control, available antibiotic disks with $10 \mu \mathrm{g} / \mathrm{ml}$ streptomycin (BBL) and tetracycline (BBL) were also added onto the inoculated plates. For the negative control, the solvent acetone was used. The dried antibiotic disks containing lichen crude extracts were then placed onto the surface of the inoculated MHA. All culture plates (in triplicates) were incubated for 18-24 hrs at $37^{\circ} \mathrm{C}$. Following incubation, zones of inhibition were measured with a ruler and recorded. Inhibition zones of the control (acetone), if present, were deducted from those of the lichen crude extracts. Bioactivity was 
Table 1 Species of Usnea tested for their secondary metabolite profiles and antibacterial activities.

\begin{tabular}{|c|c|c|c|c|c|c|c|}
\hline Code & Taxon & Atranorin & Barbatic & Consalazinic & Diffractaic & Galbinic & Homosekikaic \\
\hline \multicolumn{8}{|c|}{$\overline{\text { Benguet Province }}$} \\
\hline Ufr* & U. fragilescens ${ }^{1}$ & -2 & - & + & + & - & - \\
\hline $\mathbf{U g l} *$ & U. glabrata & - & - & + & - & - & - \\
\hline Uce & U. ceratina & - & - & + & - & + & - \\
\hline Uss* & U. subscabrosa & - & - & + & - & + & - \\
\hline Uru & U. rubicunda & - & - & - & - & - & - \\
\hline Uhi & U. hirta & - & - & - & - & - & - \\
\hline Usc & U. subcornuta & - & - & - & - & - & - \\
\hline Uco & U. cornuta & - & - & + & + & + & - \\
\hline Usc* & U. subcornuta & - & - & + & - & - & - \\
\hline Uhe & U. hesperina & - & - & + & - & - & - \\
\hline Uhe* & U. hesperina & - & - & + & - & + & - \\
\hline Uru* & U. rubicunda & - & - & + & - & + & - \\
\hline \multicolumn{8}{|c|}{ Nueva Vizcaya Province } \\
\hline Ufr* & U. fragilescens & - & - & - & - & - & - \\
\hline Uhe* & U. hesperina & - & - & - & - & - & - \\
\hline Uru* & U. rubicunda & + & - & - & - & + & - \\
\hline \multicolumn{8}{|c|}{ Ifugao Province } \\
\hline Uce* & U. ceratina & - & - & + & - & - & - \\
\hline Ula* & U. lapponica & - & - & - & + & - & - \\
\hline Uce* & U. ceratina & - & - & + & + & - & - \\
\hline Uba* & U. baileyi & - & - & + & + & - & + \\
\hline Uhi* & U. hirta & - & - & - & - & - & - \\
\hline Ugla & U. glabrata & - & - & - & + & - & + \\
\hline Uce* & U. ceratina & - & - & - & + & - & + \\
\hline Usc* & U. subcornuta & - & - & - & + & - & + \\
\hline Uco & U. cornuta & - & - & - & - & - & - \\
\hline Ufr & U. fragilescens & - & - & - & - & - & - \\
\hline Uco & U. cornuta & - & - & + & + & - & - \\
\hline Uin* & U. intermedia & - & - & - & - & - & - \\
\hline Uss & U. subscabrosa & - & - & - & - & - & - \\
\hline Uhe & U. hesperina & - & - & - & + & - & - \\
\hline Ugla* & U. glabrata & - & - & - & - & - & - \\
\hline Uni* & U. nidulans & - & - & + & + & - & - \\
\hline Uru* & U. rubicunda & + & - & + & - & + & - \\
\hline Uss* & U. subscabrosa & + & + & + & - & - & - \\
\hline Uch* & U. chaetophora & - & - & - & - & - & - \\
\hline Uha* & U. haumanii & - & - & - & - & - & - \\
\hline Uss* & U. subscabrosa & - & - & + & - & - & - \\
\hline Uar* & U. articulata & - & - & - & - & - & - \\
\hline Usb* & U. schadenbergiana & - & - & + & - & - & - \\
\hline \multicolumn{8}{|c|}{ Cavite Province } \\
\hline Ufr & U. fragilescens & - & - & - & - & - & - \\
\hline \multicolumn{8}{|c|}{ Mountain Province } \\
\hline Uar & U. articulata & - & - & - & - & - & - \\
\hline Uso* & U. sorediosula & - & - & + & - & - & - \\
\hline$\overline{\text { Code }}$ & Taxon & Hypoconstictic & Hyposalazinic & Hypostictic & Manegazziaic & Micareic & Norstictic \\
\hline
\end{tabular}

\section{Benguet Province}

$\begin{array}{ll}\text { Ufr* } & \text { U. fragilescens } \\ \text { Ugl* } & \text { U. glabrata } \\ \text { Uce } & U . \text { ceratina } \\ \text { Uss* } & \text { U. subscabrosa } \\ \text { Uru } & U . \text { rubicunda } \\ \text { Uhi } & U . \text { hirta } \\ \text { Usc } & U . \text { subcornuta } \\ \text { Uco } & U . \text { cornuta } \\ \text { Usc* } & U . \text { subcornuta } \\ \text { Uhe } & U . \text { hesperina }\end{array}$


Mycosphere Doi 10.5943/mycosphere/4/2/10

\begin{tabular}{|c|c|c|c|c|c|c|c|}
\hline Code & Taxon & Hypoconstictic & Hyposalazinic & Hypostictic & Manegazziaic & Micareic & Norstictic \\
\hline Uhe* & U. hesperina & + & - & + & + & - & + \\
\hline Uru* & U. rubicunda & + & - & - & + & - & + \\
\hline \multicolumn{8}{|c|}{ Nueva Vizcaya Province } \\
\hline Ufr* & U. fragilescens & - & - & + & - & - & - \\
\hline Uhe* & U. hesperina & - & - & - & - & - & - \\
\hline Uru* & U. rubicunda & + & - & - & + & - & + \\
\hline \multicolumn{8}{|c|}{ Ifugao Province } \\
\hline Uce* & U. ceratina & - & - & - & + & - & - \\
\hline Ula* & U. lapponica & - & - & - & + & - & - \\
\hline Uce* & U. ceratina & - & + & - & + & - & + \\
\hline Uba* & U. baileyi & - & + & - & + & - & + \\
\hline Uhi* & U. hirta & - & - & - & + & + & + \\
\hline Ugla & U. glabrata & - & - & - & - & - & - \\
\hline Uce* & U. ceratina & - & + & - & + & - & + \\
\hline Usc* & U. subcornuta & - & + & - & + & - & + \\
\hline Uco & U. cornuta & - & - & - & + & + & + \\
\hline Ufr & U. fragilescens & - & - & - & - & - & + \\
\hline Uco & U. cornuta & - & - & - & + & + & + \\
\hline Uin* & U. intermedia & - & - & - & + & - & - \\
\hline Uss & U. subscabrosa & - & - & - & + & - & - \\
\hline Uhe & $U$. hesperina & - & - & - & + & + & + \\
\hline Ugla* & U. glabrata & - & + & - & + & + & + \\
\hline Uni* & U. nidulans & - & + & - & + & + & + \\
\hline Uru* & U. rubicunda & - & + & - & + & - & + \\
\hline Uss* & U. subscabrosa & - & - & - & + & - & + \\
\hline $\mathrm{Uch} *$ & U. chaetophora & - & - & - & + & + & + \\
\hline Uha* & U. haumanii & - & + & - & + & + & + \\
\hline Uss* & U. subscabrosa & - & + & - & + & + & + \\
\hline Uar* & U. articulata & - & + & - & + & + & + \\
\hline Usb* & U. schadenbergiana & - & + & - & - & - & + \\
\hline \multicolumn{8}{|c|}{ Cavite Province } \\
\hline Ufr & U. fragilescens & - & + & - & + & - & + \\
\hline \multicolumn{8}{|c|}{ Mountain Province } \\
\hline Uar & U. articulata & - & - & - & + & - & - \\
\hline Uso* & U. sorediosula & - & - & - & - & + & - \\
\hline Code & Taxon & Salazinic & Sekikaic & Stictic & Usnic & Zeorin & \\
\hline
\end{tabular}

Benguet Province

$\begin{array}{ll}\text { Ufr* } & \text { U. fragilescens } \\ \text { Ugl* } & \text { U. glabrata } \\ \text { Uce } & \text { U. ceratina } \\ \text { Uss* } & \text { U. subscabrosa } \\ \text { Uru } & \text { U. rubicunda } \\ \text { Uhi } & \text { U. hirta } \\ \text { Usc } & U . \text { subcornuta } \\ \text { Uco } & U . \text { cornuta } \\ \text { Usc* } & \text { U. subcornuta } \\ \text { Uhe } & U . \text { hesperina } \\ \text { Uhe* } & U . \text { hesperina } \\ \text { Uru* } & \text { U. rubicunda }\end{array}$

Nueva Vizcaya Province
Ufr*
U. fragilescens
Uhe*
$U$. hesperina
Uru*
U. rubicunda

Ifugao Province

\begin{tabular}{llllll} 
Uce* & U. ceratina & + & - & - & + \\
Ula* & U. lapponica & - & + & - & + \\
Uce* & U. ceratina & + & + & - & + \\
\hline
\end{tabular}


Mycosphere Doi 10.5943/mycosphere/4/2/10

\begin{tabular}{|c|c|c|c|c|c|c|}
\hline Code & Taxon & Salazinic & Sekikaic & Stictic & Usnic & Zeorin \\
\hline Uba* & U. baileyi & + & + & - & + & - \\
\hline Uhi* & U. hirta & + & - & - & + & - \\
\hline Ugla & U. glabrata & + & + & - & + & - \\
\hline Uce* & U. ceratina & + & + & - & + & - \\
\hline Usc* & U. subcornuta & + & + & - & + & - \\
\hline Uco & U. cornuta & + & - & - & + & - \\
\hline Ufr & U. fragilescens & - & - & + & + & - \\
\hline Uco & U. cornuta & - & + & + & + & - \\
\hline Uin* & U. intermedia & + & - & - & + & - \\
\hline Uss & U. subscabrosa & + & - & - & + & - \\
\hline Uhe & U. hesperina & - & - & - & + & - \\
\hline Ugla* & U. glabrata & + & - & - & + & - \\
\hline Uni* & U. nidulans & - & - & - & + & + \\
\hline Uru* & U. rubicunda & + & + & - & + & - \\
\hline Uss* & U. subscabrosa & + & - & - & + & - \\
\hline Uch* & U. chaetophora & + & - & - & + & - \\
\hline Uha* & U. haumanii & + & - & - & + & - \\
\hline Uss* & U. subscabrosa & + & - & - & + & - \\
\hline Uar* & U. articulata & + & - & - & + & - \\
\hline Usb* & U. schadenbergiana & + & - & - & + & - \\
\hline \multicolumn{7}{|c|}{ Cavite Province } \\
\hline Ufr & U. fragilescens & + & - & + & + & - \\
\hline \multicolumn{7}{|c|}{ Mountain Province } \\
\hline Uar & U. articulata & + & - & - & + & - \\
\hline Uso* & U. sorediosula & + & - & - & + & - \\
\hline
\end{tabular}

*Lichen extracts used in anti-tubercular assay.

${ }^{1}$ Lichens in bold were used in TLC-bioautography for the detection of bioactive lichen acids.

$2(+)=$ Lichen acid detected; $(-)=$ lichen acid not detected

Table 2 Lichen metabolites detected from the 18 Usnea species using three solvent systems on TLC.

\begin{tabular}{lccc}
\hline \multicolumn{1}{c}{ Lichen Metabolite } & \multicolumn{3}{c}{${ }^{\mathrm{a}}$ Solvent Systems } \\
\hline Atranorin & $0^{\mathrm{b}}$ & $\mathrm{C}$ & $\mathrm{G}$ \\
Barbatic acid & 0 & 1 & 1 \\
Consalazinic acid & 1 & 0 & 0 \\
Diffractaic acid & 0 & 0 & 1 \\
Galbinic acid & 1 & 1 & 1 \\
Homosekikaic acid & 0 & 1 & 1 \\
Hypoconstictic & 0 & 0 & 0 \\
Hyposalazinic acid & 1 & 1 & 1 \\
Hypostictic acid & 1 & 0 & 0 \\
Manegazziaic acid & 1 & 0 & 1 \\
Micareic acid & 1 & 1 & 1 \\
Norstictic acid & 0 & 1 & 0 \\
Salazinic acid & 0 & 1 & 1 \\
Sekikaic acid & 1 & 1 & 1 \\
Stictic acid & 1 & 1 & 0 \\
Usnic acid & 1 & 1 & 1 \\
Zeorin & 1 & 0 & 0 \\
Total & $\mathbf{1 0}$ & $\mathbf{1 1}$ & $\mathbf{1 1}$ \\
\hline
\end{tabular}

${ }^{a}$ Solvent System A: 36:9:1 toluene/dioxane/glacial acetic acid

Solvent System C: 20:3 toluene/glacial acetic acid

Solvent System G: 139:83:8 toluene/ethylacetate/formic acid

b $1=$ detected; $0=$ not detected 
assessed as follows: (1) very active, $>19 \mathrm{~mm}$ zone of inhibition, (2) active, 13-19 $\mathrm{mm}$ zone of inhibition, (3) partially active, $10-12 \mathrm{~mm}$ zone of inhibition, and (4) inactive, $<10 \mathrm{~mm}$ zone of inhibition (Quinto \& Santos 2005).

From the 41 lichen crude extracts, 28 were chosen and tested for their anti-tubercular activities against $M$. phlei (Table 1). Paper disk diffusion assay was done as previously described. As positive control, the antibiotics streptomycin, isoniazid (BBL, USA, $1 \mu \mathrm{g} / \mathrm{ml}$ ) and ampicillin (BBL, USA, $10 \mu \mathrm{g} / \mathrm{ml}$ ) were used. Zones of inhibition were measured and assessed following the methods of Quinto \& Santos (2005). To test for significant differences, the mean zones of inhibition for each lichen crude extracts against the test bacteria were subjected to one-way analysis of variance (ANOVA) using SigmaStat ver 8.0 (Systat Software, USA).

$T L C$-Bioautography. To determine the bioactive lichen acid/s, 15 lichen crude extracts exhibiting distinct spots in their TLC were chosen and then, initially spotted on a new TLC plate (Table 2). The TLC plate was then run in solvent system $\mathrm{G}$ and the lichen spots visualized under $U V$ light at $254 \mathrm{~nm}$ wavelength. Then, the TLC plate was allowed to air-dry for at least 30 minutes to remove any traces of the solvent system. A bacterial suspension was prepared from a 24-hour old $N$. asteroides and the concentration of the inoculum was adjusted to 0.5 McFarland Standard. Then, $80 \mu \mathrm{l}$ of the bacterial suspension was mixed with $80 \mathrm{ml}$ cooled, semi-solid, sterile Nutrient Agar (with $0.2 \%$ agar) and was designated as the seeded layer. A base medium (approximately $80 \mathrm{ml}$ solidified NA) was also prepared and poured on sterile, rectangular petri plate. To the NA base medium, the air-dried TLC plate was placed on top. The seeded layer was poured over the TLC plate and allowed to solidify. Following incubation at $37^{\circ} \mathrm{C}$ for 24 hours, the spots with zones of inhibition were identified following comparison with the visualized TLC plates previously done.

\section{Results}

\section{Metabolic Profiling of Usnea species}

In the study, 41 specimens of 18 species of Usnea were profiled using TLC. The extracted lichen acids had a percent yield ranging from $0.53-10.14 \%$ or 5.3 to $101.4 \mathrm{mg}$ per 1 gram air-dried lichen thalli (data not shown). Among the collected specimens, $U$. articulata had a maximum yield of $10.14 \%$ of the total dried weight while $U$. hesperina had the lowest yield of $0.53 \%$. Solvent system A detected 10 lichen metabolites (Table 2). Interestingly, zeorin was detected only in this solvent system. The TLC profiles run on solvent systems $\mathrm{C}$ and $\mathrm{G}$ both detected 11 lichen metabolites (Table 2). Homosekikaic acid and barbatic acid were unique to solvent system $\mathrm{C}$ while diffractaic acid and hypoconstictic acid were found only with solvent system $G$ (Table 2). In addition, galbinic acid, sekikaic acid, and usnic acid were detected in all solvent systems used. Thus, a total of 17 different lichen acids were detected using TLC from the 18 Usnea species.

In this study, depsides and depsidones were reported in 14 species of Usnea. In addition to these, several lichen acids (atranorin, galbinic, norstictic, salazinic and sekikaic acids, to name a few) were detected that could be potentially bioactive (Fig. 1).

\section{Antibacterial Activities of Lichen Extracts}

Against Gram-positive Bacteria. As a general rule, most of the lichen extracts were more active against gram-positive bacteria using paper disk diffusion assay (Fig. 2). Nine of the 41 lichen crude extracts were found to be active (13-19 mm ZOI) against $S$. aureus with zones of inhibition comparable with that of the control antibiotic streptomycin (Fig. 2). Among the 41 lichen crude extracts, $U$. fragilescens (Ufr13), $U$. ceratina (Uce17), and $U$. esperantiana (Ues41) had the highest mean ZOI (>15 mm). Most of the specimens were either partially active $(10-12 \mathrm{~mm}$ ZOI) or inactive ( $<10 \mathrm{~mm} \mathrm{ZOI}$ ) (Fig. 3). On the other hand, most crude extracts were active (13-19 $\mathrm{mm}$ ZOI) and very active (>19 $\mathrm{mm} \mathrm{ZOI)}$ against $B$. subtilis (Fig. 2, 3). Among the crude extracts tested, $U$. glabrata (Ug102), $U$. ceratina (Uce03), and U. hesperina (Uhe11) had the highest mean ZOI (>19mm). Some of the zones of inhibition exhibited were even bigger or larger than with the antibiotics streptomycin and tetracycline (Fig. 2). 


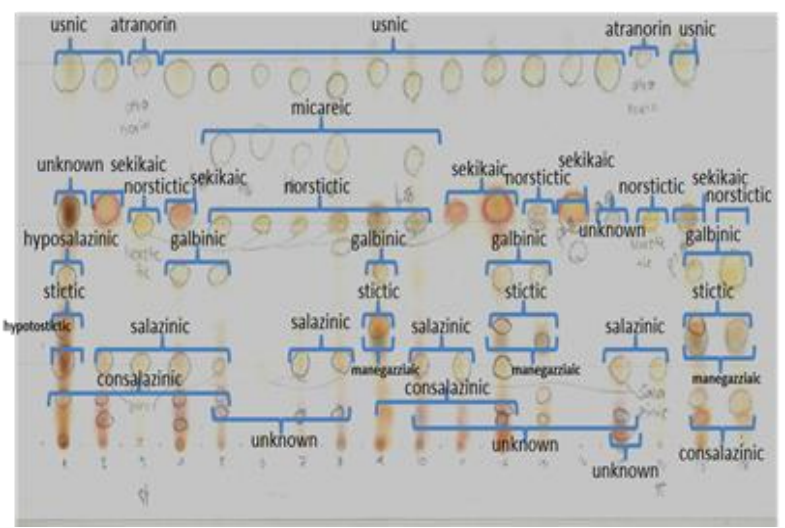

(A) Solvent System A: 36:9:1 toluene/dioxane/glacial acetic acid

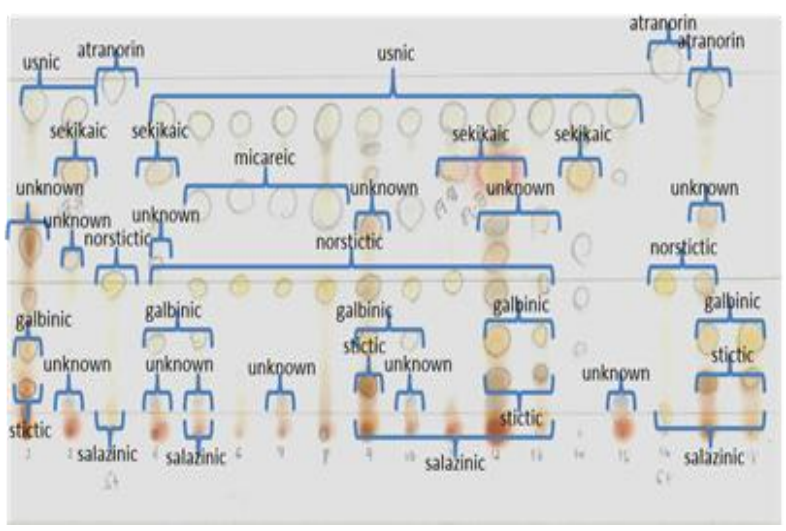

(B) Solvent System C: 20:3 toluene/glacial acetic acid

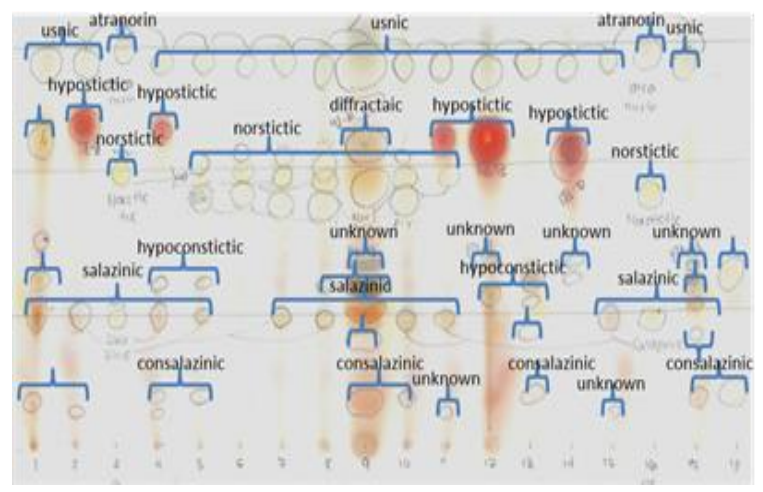

(C) Solvent System G: 139:83:8 toluene/ethyl acetate/formic acid

Fig. 1 - TLC plates showing the lichen acids detected in Usnea species.

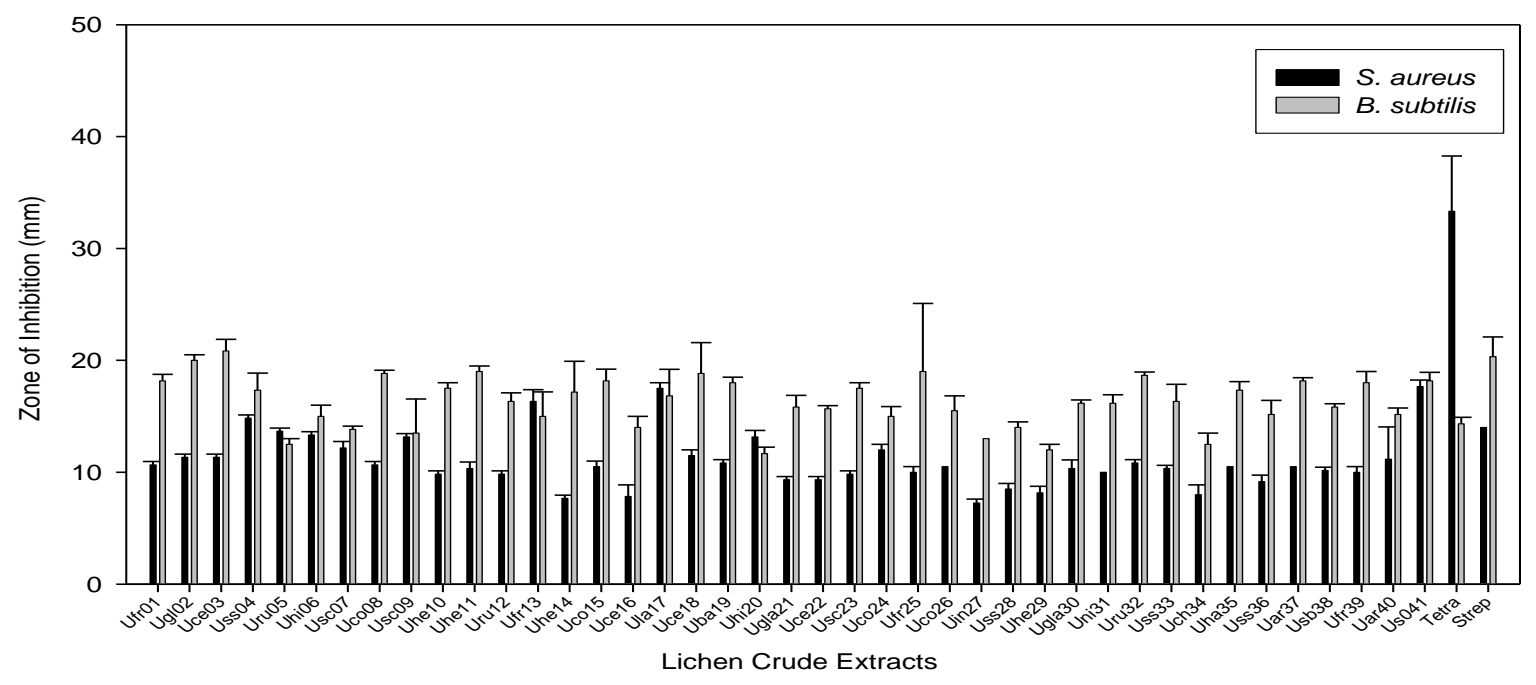

Fig. 2 - Zones of inhibition exhibited by 41 lichen crude extracts of Usnea spp. against grampositive bacteria $S$. aureus and $B$. subtilis. Standard deviations are indicated above each bar (p $<0.01)$. 


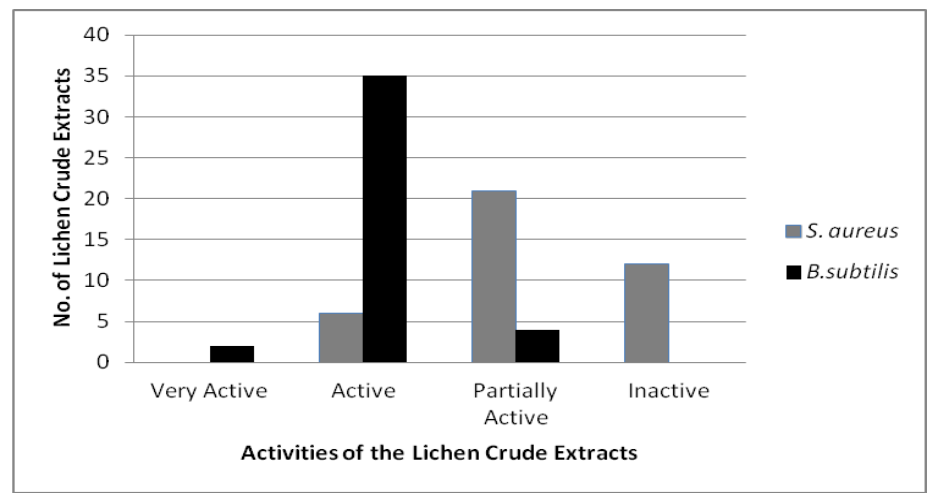

Fig. 3 - Bioactivities of the crude extracts of Usnea spp. against gram-positive bacteria. Bioactivities: (1) Very Active, $>19$ mm ZOI, (2) Active, 13-19 mm ZOI, (3) Partially Active, 10-12 $\mathrm{mm}$ ZOI, and (4) Inactive, $<10 \mathrm{~mm}$ ZOI.

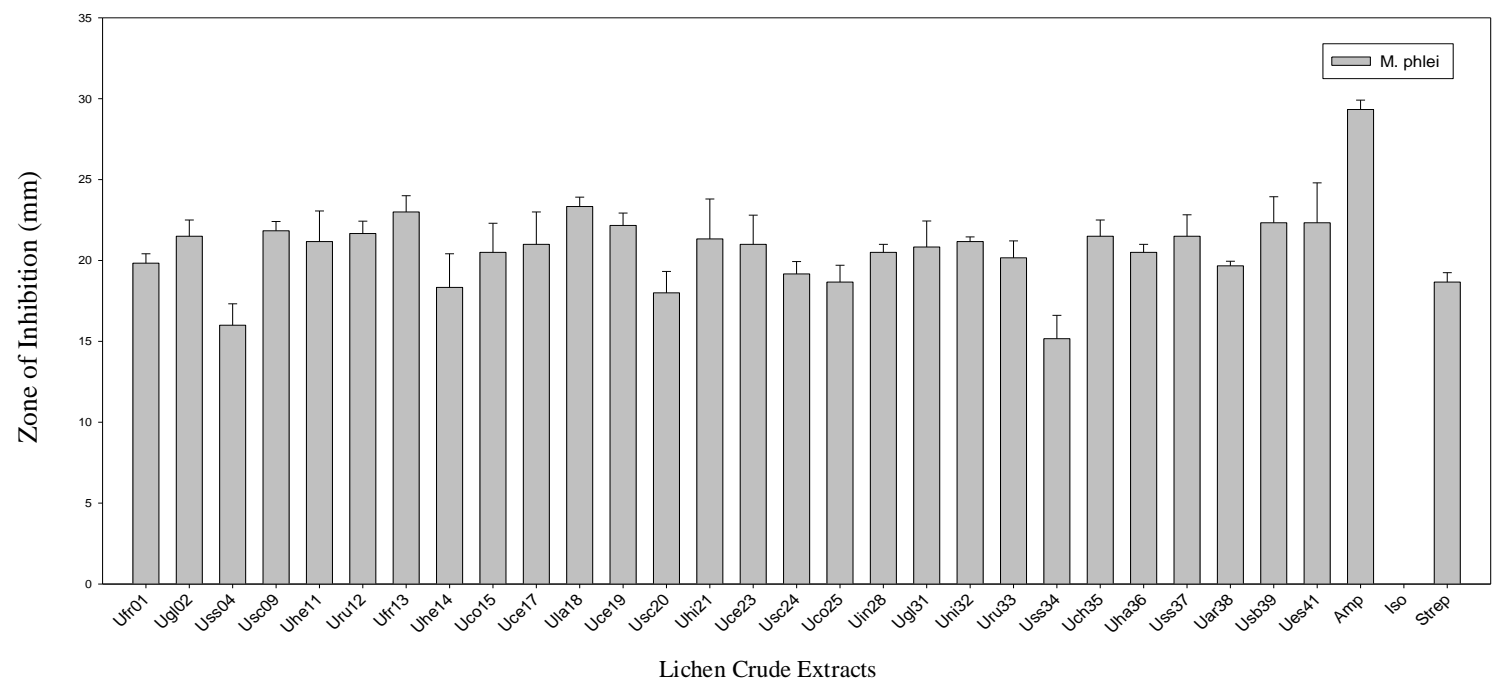

Fig. 4 - Zones of inhibition exhibited by the 28 lichen crude extracts of Usnea spp. against $M$. phlei. Standard deviations are indicated above each bar $(\mathrm{p}<0.01)$.

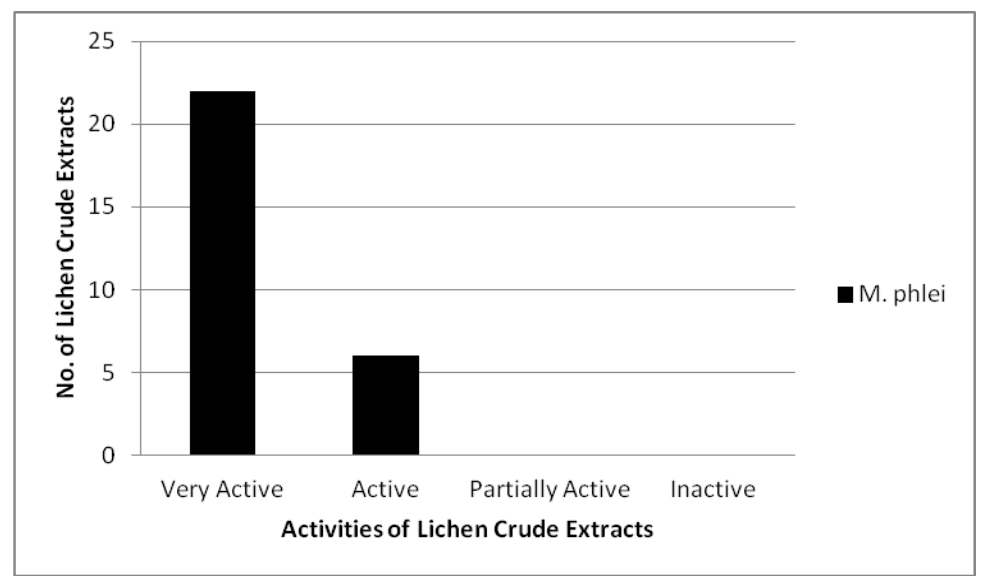

Fig. 5 - Bioactivities of the lichen crude extracts of Usnea spp. against M. phlei. 


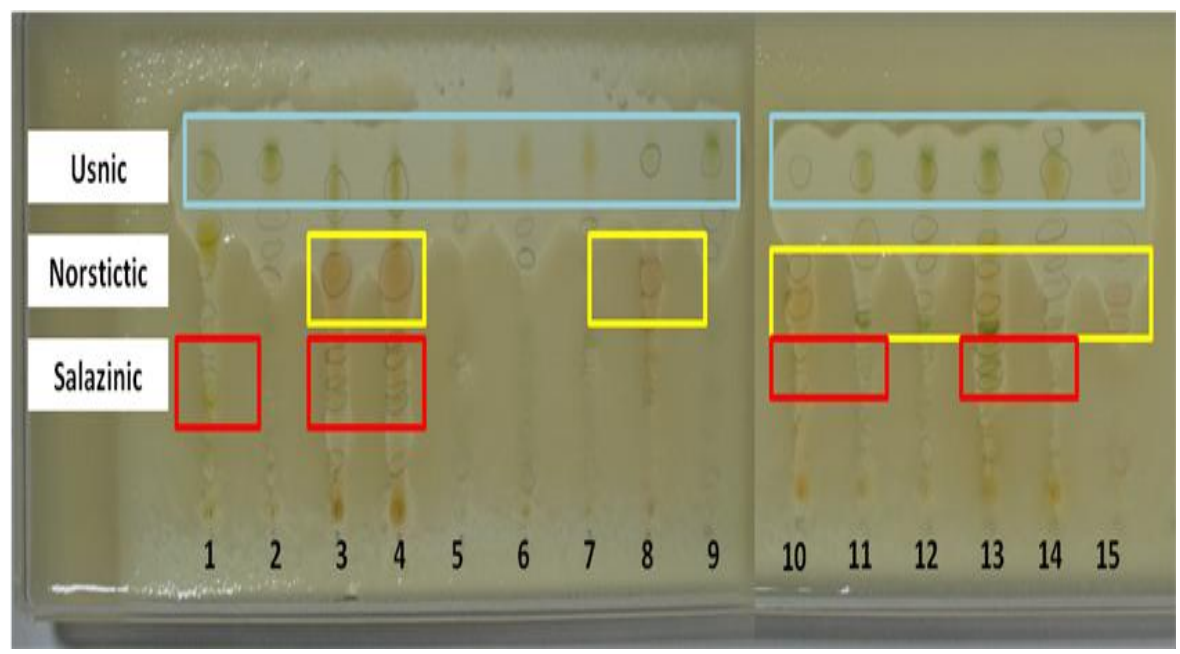

Fig. 6 - Bioactive lichen metabolites of Usnea species tested against $N$. asteroides. (1Ufr, 2 Ugla, 3 Uss, 4 Usc, 5 Uru, 6 Uhe, 7 Uru, 8 Uba, 9 Uce, 10 Uco, 11 Ugla, 12 Uni, 13 Uar, 14 Usb, 15 Uso)

However, it can be noted that among grampositive bacteria, differences in inhibitory activities were observed. As mentioned, more Usnea species were active against $B$. subtilis than $S$. aureus. Thus, it is necessary to test other gram-positive bacteria even for those extracts that exhibited minimal activity against S. aureus. Against Acid-Fast Bacilli. In our study, 28 lichen crude extracts were further tested against $M$. phlei (Fig. 4). This bacterium was used since it is a non-pathogenic organism but with a similar sensitivity profile to $M$. tuberculosis. Our result showed that most of the crude extracts of Usnea were very active (>19 mm ZOI) against M. phlei (Fig. 5). U. lapponica (Ula18), U. ceratina (Uce19), $U$. subscabrosa (Usb39), and U. esperantiana (Ues41) had the highest mean ZOI (>21 mm). Interestingly, the crude extracts gave larger zones of inhibition than the control antibiotics isoniazid and streptomycin (Fig. 4), and thus, showed their potential as component of antituberculosis drugs. Among the lichen acids detected in our study, diffractaic acid, norstictic acid, and usnic acid were recorded from the TLC profiles. Perhaps, the bioactivity exhibited by our Usnea species against M. phlei could also be attributed to these lichen acids. However, at present, the modes of action of these secondary metabolites are still unknown. TLC-Bioautography. TLC-Bioautography can be used to detect unidentified bioactive lichen metabolites against a test organism. In this study, 15 lichen crude extracts of Usnea were tested against $N$. asteroides to determine the bioactive lichen metabolite/s (Fig. 6). $N$. asteroides, an actinobacterium, was used since it is non-pathogenic and with similar sensitivity profile to $M$. tuberculosis. Based on the results, the bioactive metabolites were identified as usnic acid, nostictic acid and salazinic acid as shown in the clearing zone around these spots on the TLC plate (Fig. 6).

\section{Discussions}

The lichen symbioses are considered to be one of the most successful interactions in nature. From various habitats with different extremities ranging from very cold to very hot places, a number of lichens can be found. Interestingly, these unique organisms offer many bioactive secondary metabolites with manifold biological activities. As symbiotic organisms, lichens are known to synthesize lichen metabolites (Huneck 1999, Rankovic et al. 2007). All of these lichen metabolites were of fungal origin (Elix \& Stocker-Wörgötter 2008). These include aliphatic acids, pulvinic acid derivatives, hydroxybenzoic acid derivatives, depsides, depsidones, dibenzofuran derivatives, anthraquinones, naphthoquinones and related compounds, and epidithiopiperazinediones (Müller 2001). The application of TLC in lichens began after the observation of several experimental problems (poor spot resolution, low sensitivities, and long analysis times) on paper chromatography (Elix \& Stocker-Wörgötter 2008). TLC now is 
widely used for identifying lichen products. This technique allows rapid detection of several lichen acids belonging to different classes by means of simple and inexpensive methods (Elix \& Stocker-Wörgötter 2008). It uses commercially available silica gel TLC plates and employs the usage of different solvent systems (designated as A, B, C, E and $\mathrm{G})$ and two internal controls (atranorin and norstictic acid) to which all $\mathrm{Rf}$ values are compared (Elix \& Stocker-Wörgötter 2008). Acetone is also used to extract secondary metabolites since most of the lichen metabolites are soluble with this organic solvent (Huneck \& Yoshimura 1996). In this study, lichen acids from several species of Usnea were extracted with acetone and run on TLC with three solvent systems to detect their lichen metabolites.

Of the hundred known secondary metabolites from lichens, the dibenzofuran derivative usnic acid is of no doubt the most extensively studied (Ingólfsdóttir 2002). Lichens containing usnic acid have been used as crude drugs throughout the world (Ingólfsdóttir 2002). Interestingly, usnic acid is known to have activity against gram-positive bacteria, mycobacteria, VRE, and MRSA (Francolini et al. 2004, Elo et al. 2007). All of the 18 Usnea species in the study showed the presence of usnic acid (Fig. 1). Another lichen metabolite of medical significance is the protolichesterinic acid. This has been reported to exhibit in vitro activity against Helicobacter pylori (Ingólfsdóttir 1997). In addition, depsides and depsidones were reported to have antioxidant activity (Hidalgo et al. 1994).

Differences in lichen profiles were reported here (Table 1-2, Fig. 1). The variations observed among the specimens are indicative of three reasons: (1) differences in mycobionts, (2) total loss of major compounds, and (3) involvement of secondary products with very different biosynthetic origins (Fahselt 1996). There may be cases when the levels of lichen metabolites differ significantly between thalli of the same species growing in the same substrate (Fahselt 1996). Moreover, a mutation may modify a particular pathway accounting for the loss of lichen metabolite normally present in a species' thallus, e.g., usnic acid-deficient strains of Cladina (Fahselt
1996). In addition, involvement of "different" secondary products may also contribute to variations. These secondary products are often associated with particular ecological settings or geographic areas, but may also occur together in the same habitat (Fahselt 1996).

Lichen metabolites had reported antibacterial, antifungal, anti-parasitic, antihelmintic, anti-inflammatory and anti-viral activities (Rankovic et al. 2007). For example, extracts of the lichen Ramalina farinacea were reported to have antibacterial, antifungal and cytotoxic properties (Esimone \& Adikwu 1999). Interestingly, extracts of Parmelia saxatilis, Platismatia glauca, Ramalina pollinaria, $R$. polymorpha and Umbilicaria nylanderiana were reported to have activities against bacteria, fungi and yeast and possess antioxidant properties (Gulluce et al. 2006). In the Philippines, Santos et al. (1964) showed antibiotic activities of the lichens Crocynia membranacea, Stereocaulon sp., Ramalina farinacea, Parmelia dactylifera, Physcia albicans, Lecanora subfusca and Usnea sp.. Recently, Santiago et al. (2010) reported inhibitory activities of the lichens Usnea baileyi, Ramalina dendriscoides, Cladonia gracilis and Stereocaulon massartianum against gram-positive bacteria. These are just few literatures that supported the potentials of lichens as sources of bioactive metabolites. In this study, the different Usnea species were found active against gram-positive bacteria and acid-fast bacilli (Fig. 2-4). This study also further confirmed what is known of the activity of the lichen acids against gram-positive bacteria (Santos et al. 1964, Saenz et al. 2006, Rankovic et al. 2007, Santiago et al. 2010). Several other studies have also reported antimycobacterial activity of lichens (Ingólfsdóttir et al. 1998, Gupta et al. 2007, Honda et al. 2010). Diffractaic, norstictic acid and usnic acid were the active compounds inhibiting the growth of M. tuberculosis (Honda et al. 2010).

Although the modes of action of the lichen metabolites were not determined in this study, other researchers have proven that the antibacterial effect of lichen acids was due to the inhibition of the oxidative phosphorylation of the cell (Ingólfsdóttir, 2002; Elix \& StockerWörgötter, 2008). The lichen metabolite usnic acid has active centers, i.e. benzofuran or 
dihydrobenzofuran nucleus, the phenolic hydroxyl groups and the 4,4a-double bond in the dihydroaromatic ring, which target the bacterial cells (Elix \& Stocker-Wörgötter, 2008). As the inhibition of oxidative phosphorylation continues, oxygen consumption, electron transport chain and other mitochondrial functions will be inhibited (Frankos, 2005). Perhaps, this could also explain the inhibitory activities observed in the lichen acids extracted from Usnea species in this study.

Tuberculosis is an infectious disease responsible for approximately 2 million deaths annually (Honda et al., 2010). Since there is an emergence of multi-drug resistant strains of Mycobacterium tuberculosis, the search for an effective drug is of great importance. Interestingly, secondary metabolites produced by lichens are known to have anti-tubercular activities (Ingólfsdóttir, 1998; Gupta et al., 2007; Honda et al., 2010). Usnic acid, for example, was recently reported to be active against M. tuberculosis (Ingólfsdóttir, 1998; Honda et al., 2010). Thus, it is important that the different Usnea species be tested for their inhibitory activities against acid-fast bacilli (Fig. 4).

It was also reported that fruticose lichens possessed bioactive lichen acids (Santiago et al., 2010). Extracts of Usnea baileyi, Ramalina dendriscoides, Stereocaulon massartianum and Cladonia gracilis were tested against $S$. aureus and were reported to have seven bioactive lichen acids: usnic acid, norstictic acid, salazinic acid, stictic acid, diffractaic acid, barbatic acid and galbinic acid. In this study, three of the lichen acids previously reported to be bioactive against $S$. aureus was again reported as bioactive against $N$. asteroides. The antibiotic activity could be due to the inhibition of oxidative phosphorylation, thereby, inhibiting oxygen consumption, electron transport chain and mitochondrial function of the bacteria (Nash, 1996; Frankos, 2005). Though the mode of action was not studied in the bioactive lichen metabolites, these could also explain the bioactivities exhibited by the Usnea against $N$. asteroides.

In summary, lichens are indeed prolific sources of bioactive secondary metabolites.
Majority of the lichen crude extracts have shown excellent activities against selected test bacteria. Thus, this study has just once again proven the effectiveness of these "untapped organisms" against the emerging and reemerging pathogenic microorganisms. As more lichen metabolites will be investigated, the chance of these "re-born microorganisms" to survive minimizes.

\section{Acknowledgements}

KAAS would like to acknowledge the Department of Science and Technology (DOST) - Philippine Council for Health Research and Development (PCHRD) for the graduate scholarship and thesis grant. KAAS would also like to thank the whole Biology Department of Ramkhamhaeng University in Bangkok, Thailand for their generosity in providing training on TLC and TLCbioautography for the completion of this paper.

\section{References}

Bawingan PA, Flores YG, Lardizabal MP, Rosuman PF. 2000 - Flora of the Cordillera (I): Baguio-Benguet Lichens. Baguio: Saint Louis UniversityNational Research Unit.

Behera BC, Verma N, Sonone A, Makhija U. 2005 - Antioxidant and antibacterial activities of lichen Usnea ghattensis in vitro. Biotechnology Letters 27, 991995.

Boustie J, Grube M. 2005 - Lichens - a promising source of bioactive secondary metabolites. Plant Genetic Resources 3(2), 273-287.

Butler MS, Buss AD. 2006 - Natural products - the future scaffolds for novel antibiotics? Biochemical Pharmacology 71, 919-929.

Culberson CF 1972 - Improved conditions and new data for the identification of lichen products by a standardized thin-layer chromatographic method. Journal of Chromatography 72, 113-125.

Elix JA, Stocker-Wörgötter E. 2008 Biochemistry and secondary metabolites. In: Nash, T.H. III (Ed.). Lichen Biology. Cambridge University Press, Cambridge, New York 104-133. 
Elo H, Matikainen J, Pelttari E. 2007 - Potent activity of the lichen antibiotic (+)usnic acid against clinical isolates of vancomycin-resistant enterococci and methicillin-resistant Staphylococcus aureus. Naturwissenschaften 94, 465468.

Esimone CO, Adikwu MU 1999 Antimicrobial activity and cytotoxicity of Ramalina farinacea. Fitoterapia 70, 428-431.

Fahselt D 2006 - Individuals and populations of lichens. In: Nash T.H. III (Eds). Lichen Biology. Cambridge University Press, Cambridge, New York, 252-273.

Francolini I, Norris P, Piozzi A, Donelli G, Stoodley P. 2004 - Usnic acid, a natural antimicrobial agent able to inhibit bacterial biofilm formation on polymer surfaces. Antimicrobial Agents and Chemotherapy 48(11), 4360-4365.

Frankos V 2005 - NTP nomination for usnic acid and Usnea barbata herb. Submitted by the Food and Drug Administration, Division of Dietary Supplement

Program. http://ntp.niehs.nih.gov/ntp/htdocs/Che m_Background/ExSumPdf/UsnicAcid.p df.

Goward T 1999 - The lichens of British Columbia. Ministry of Forests Research Program. Special Report. Crown Publications, Canada.

Gulluce M, Aslan A, Sokmen M, Sahin F, Adiguzel A, Agar G, Sokmen A. 2006 Screening the antioxidant and antimicrobial properties of lichens Parmelia saxatilis, Platismatia glauca, Ramalina pollinaria, Ramalina polymorpha, Umbilicaria nylanderiana. Phytomedicine 13, 515-521.

Gupta VK, Darokar MP, Saikia D, Pal A, Fatima A, Khanuja SPS. 2007 Antimycobacterial activity of lichens. Pharmaceutical Biology 45(3), 200204.

Hale M 1979 - How to know the lichens $\left(2^{\text {nd }}\right.$ ed.). Wm. C. Brown, Dubuque, Iowa.

Harvey AL 2000 - Strategies for discovering drugs from previously unexplored natural products. Drug Discovery Today 5(7), 294-300.
Harvey AL 2008 - Natural products in drug discovery. Drug Discovery Today 13(19-20), 894-901.

Hauck M, Jürgens S-R. 2008 - Usnic acid controls the acidity tolerance of lichens. Environmental Pollution 156, 115-122.

Hawksworth DL, Kik PM, Sutton BC, Pegler DN. 1995 - Dictionary of the fungi. CAB International, Wallingford.

Herre A 1963 - The lichen genus Usnea and its species at present known from the Philippines. The Philippine Journal of Science 92(1), 41-76.

Hidalgo ME, Fernandez E, Quilhot W, Lissi E - 1995. Antioxidant activity of depsides and depsidones. Phytochemistry 37 (6), 1585-1587.

Honda NK, Pavan FR, Coelho RG, Leite SR deA, Micheletti AC, Lopes TIB, Misutsu MY, Beatriz A, Brum RL, Leite CQF. 2010 - Antimycobacterial activity of lichen substances. Phytomedicine 17(5), 328-332.

Huneck S 1999 - The significance of lichens and their metabolites. Naturwissenschaften 86, 559-570.

Huneck S, Yoshimura I. 1996 - Identification of lichen substances. Springer, New York, 11-13.

Ingólfsdóttir K $2002-$ Usnic acid. Phytochemistry 61, 729-736.

Ingolfsdottir K, Chung GAC, Vilhjalmur GS, Gissurarson SF, Vilhelmsdottir M 1998 - Antimycrobacterial activity of lichen metabolites in vitro. European Journal of Pharmaceutical Sciences 6,141-144.

Ingólfsdóttir K, Chung GAC, Skúlason VG, Gissurarson SR, Vilhelmsdóttir M. 1997 - Antimycobacterial activity of lichen metabolites in vitro. European Journal of Pharmaceutical Sciences 6, 141-144.

Karagöz A, Dogruöz N, Zeybek Z, Aslan A. 2009 - Antibacterial activity of some lichen extracts. Journal of Medicinal Plants Research 3(12), 1035-1039.

Müller K 2001 - Pharmaceutically relevant metabolites from lichens. Applied Microbiology and Biotechnology 56, 916.

Nash TH III 1996 - Lichen Biology. Cambridge University Press, New York. 
Ohmura Y, Lin C-K, Wang P-H. 2010 - Three sorediate species of the genus Usnea (Parmeliaceae, Ascomycota) new to Taiwan. Memoirs of the National Science Museum 46, 69-76.

Quinto E, Santos M. 2005 - Microbiology In: Guevara BQ (Ed.). A guidebook to plant screening: phytochemical and biological. University of Santo Tomas Publishing House, España, Manila, Philippines, 77.

Quisumbing E 1951 - Medicinal plants of the Philippines. Bureau of Printing, Manila.

Randlane T, Torra T, Saag A, Saag L. 2009 Key to European Usnea species. Bibliotheca Lichenologica 100, 419462.

Ranković B, Mišić M, Sukdolak S. 2007 Antimicrobial activity of extracts of the lichens Cladonia furcata, Parmelia caperata, Parmelia pertusa, Hypigymnia physodes and Umbilicaria polyphylla. British Journal of Biomedical Science 64(4), 143-148.

Russo A, Piovano M, Lombardo L, Garbarino J, Cardile V. 2008 - Lichen metabolites prevent UV light and nitric oxidemediated plasmid DNA damage and induce apoptosis in human melanoma cells. Life Sciences 83, 468-474.

Saenz MT, Garcia MD, Rowe JG. 2006 Antimicrobial activity and phytochemical studies of some lichens from south of Spain. Fitoterapia 77, 156-159.

Santiago KA, Borricano JN, Canal JN, Marcelo DA, Perez MP, dela Cruz TE. 2010 Antibacterial activities of fruticose lichens collected from selected sites in Luzon Island, Philippines. Philippine Science Letters 3(2), 18-28.

Santos PS, Mondragon A. 1969 - Studies on the Philippine lichens, II thin-layer chromatographic study of the constituents of some lichen species. The Philippine Journal of Science 98, 297303.

Santos PS, Lat B, Palo M. 1964 - The antibiotic activities of some Philippine lichens. The Philippine Journal of Science 93, 325-335.

Turk AÖ, Yilmaz M, Kivanc M, Turk H. 2003 - The antimicrobial activity of extracts of the lichen Cetraria aculeata and its protolichesterinic acid constituent. Zeitschrift für Naturforschung 58, 850854.

Wainio EA 1909 - Lichenes insularum philippinarum II. The Philippine Journal of Science 4, 651-662.

World Health Organization 2008 - WHO global burden of disease: 2004 update. www.who.int/healthinfo/global_burden _disease/2004_report_update/en/index. html. 